\title{
Extrusion Technology: Solution to Develop Quality Snacks for Malnourished Generation
}

\author{
Neha Pathak ${ }^{*}$ and Anita Kochhar
}

Department of Food and Nutrition, Punjab Agricultural University (PAU), Punjab, India

*Corresponding author

\begin{tabular}{|l|}
\hline Ke y w o r d s \\
$\begin{array}{l}\text { Malnutrition, Food } \\
\text { safety, Bio- } \\
\text { availability }\end{array}$ \\
\hline Article Info \\
\hline $\begin{array}{l}\text { Accepted: } \\
\text { 12 December } 2017 \\
\text { Available Online: } \\
\text { 10 January } 2018\end{array}$
\end{tabular}

\section{Introduction}

In developing countries malnutrition accounts for half of the deaths of children under 5 years of age. Africa and Asia bear the greatest share of all forms of malnutrition. In 2015, more than half of all stunted children under 5 lived in Asia and more than one third lived in Africa. In 2015, more than two thirds of all

\begin{abstract}
In developing countries malnutrition accounts for half of the deaths of children under 5 years of age. Africa and Asia bear the greatest share of all forms of malnutrition. Various food processing techniques have the potential to increase the nutrient density, nutrient bioavailability, food safety, storage stability, palatability, and convenience of supplemental foods which are suitable for infant feeding. These technologies used for preparation of weaning foods include roasting, germination, milling, baking, cooking, drying, fermentation, and extrusion. A majority of world population suffers from qualitative and quantitative insufficiency of dietary protein and calories intake. In all such cases physiological maintenance and growth are impaired, and malnutrition results. In this context extrusion is a beneficial process. Extrusion is one of the commonly adopted processing technique by food industries which employs mixing, forming, texturing and cooking to develop a novel food product. It is one of the contemporary food processing technologies applied for development of variety of snacks, specialty and supplementary foods. The versatility of extrusion technology makes it convenient for development of nutritionally rich extruded products with wide range of raw material and useful as a source of vehicle for value addition. Extruded products have less moisture, longer shelf life, microbiologically safe and there are plenty of ways to make value added and fortified extruded products with combination of different raw materials. This review comprehensively covers the potential of extrusion technology in development of various types of value added extruded products that can be popularized for combating malnutrition globally.

A B S T R A C T
\end{abstract}

wasted children under 5 lived in Asia and more than one quarter lived in Africa. $66 \%$ of all stunted children live in lower-middle income countries (WHO, 2016).

The treatment and prevention of malnutrition among children includes exclusive breastfeeding for first 6 months followed by breastfeeding in combination with 
supplementary food until 24 months of age (Michaelsen et al., 2009). Processed-cereal based complementary food, commonly called as weaning food or supplementary food means foods based on cereals and/or legumes (pulses), soyabean, millets, nuts and edible oilseeds, processed to low moisture content and so fragmented as to permit dilution with water, milk or other suitable medium.(Indian standards, 2006). Affordable Nutrient dense, easily digestible and of suitable consistency supplementary food are thought to be ideal to the consumers (Imtiaz et al., 2011). Various food processing techniques have the potential to increase the nutrient density, nutrient bioavailability, food safety, storage stability, palatability, and convenience of supplemental foods which are suitable for infant feeding. These technologies used for preparation of weaning foods include roasting, germination, milling, baking, cooking, drying, fermentation, and extrusion (Bressani et al., 1984). Extrusion cooking becoming popular over common processing as it is continues process with automated control, high capacity, versatility, high productivity and low cost. In developing economies, to eradicate poverty and achieve food and nutrition security, more effort is needed in harnessing extrusion technology for producing safe food utilizing locally grown legumes and cereal grains (Filli et al., 2014).

\section{Extrusion process}

A majority of world population suffers from qualitative and quantitative insufficiency of dietary protein and calories intake. In all such cases physiological maintenance and growth are impaired, and malnutrition results. In this context extrusion is a beneficial process. Extrusion is one of the commonly adopted processing techniques by food industries which employ mixing, forming, texturing and cooking to develop a novel food product (Singh et al., 2016; Gulati, 2016). Extrusion technology is now widely used in the agri- food processing industry, where it is referred to as extrusion cooking. Food material reaches to its melting point or plasticizing point when shear energy exerted by rotating screw heats the barrel (Moscicki and Zuilichem, 2011). It is one of the contemporary food processing technologies applied for development of variety of snacks, speciality and supplementary foods [Harper and Jansen., 1985] and offers advantages of preparation of ready-to-eat foods of desired shape, size, texture and sensory characteristics at very low processing cost (Guy, 2001). The extrusion process has a potential in generating quality snack products (Charles and Brennan et al., 2016).

The potential effect of the combination of legume and cereal grains in extruded snack products

Purely cereal based food products are energy dense and incomplete in terms of the nutritional profile of proteins, legume/cereal combinations in food products when mixed together, complement one another to produce a protein of a better quality by providing to each other significant amounts of the respective limiting amino acids. Novel food products with increased nutritional quality can be developed by combining legume with cereals (Balasubramanian et al., 2011). In addition, blending protein sources (peas, Lentils) with starch sources (wheat, barley and rice) produces high quality nutritious snacks (boye et al., 2010). It is a well-known fact that addition of legumes to cereals increases both content and quality of the protein mix. Oyango (2005) reported the process optimization for the production of high energy dense fermented or acidified and extruded uji, a traditional staple in East Africa. Development of an acceptable nutritious soy fortified snack by EC was reported by Boonyasirikool and Charaunuch (2000) and Riaz (2013). The former reported that there was a greater quantity of lysine and methionine plus cystine; 
and all those essential amino acids accounted for at least $80 \%$ of the recommended value (FAO/ WHO, 1973). Furthermore, the product had a good content of micronutrients, such as vitamin B-6, B-2, calcium, and sodium, and rich in $\mathrm{B}-12$ and iodine.

\section{Blending cereals and legumes for extruded products}

With the prevalence of malnutrition due to the high cost of animal protein foods and lower earning power, there is a need to look into ways of enriching traditional products that are shelf stable and acceptable.

\section{Extrusion technology as vehicle for value addition}

There are plenty of extruded products depending on the ingredients or combination of different ingredients used, i.e. ready to eat cereal, snack foods, textured vegetable protein, pasta products, meat products, pet food and animal feed. The raw materials in the extrusion cooking processes cover various combinations of ingredients including: cereals, grains and starches, tubers, legumes, oil seeds, pseudocereals, as well as animal fat and proteins. Value addition of extruded products involves incorporation of ingredients into the extruded products in order to enhance their textural or nutritional quality. Extrusion technology to some extent may improve bioavailability of bioactive compounds by forming complex with protein which could be broken down easily in human body thus Enrichment of extruded snacks with several fruit and vegetables by-products are being developed to increase the level of bioactive in extrudates (Brennan et al., 2011).

\section{Extruded products of plant origin}

Plant-based foods are the primary source of human nutrition as they are rich in carbohydrates, protein and fibers (Kumar et al., 2010). Extruded snacks made of plant sources corn and soy blends have seen increasing weight of rats than those fed with skimmed milk powder (SMP) diet as control (Baskaran and Bhattacharaya, 2004).

Optimised weaning mix was developed using extrudates of maize (Zea mays) and mungbean (Vignaradiata) flour with high protein and starch digestibility (Salim et al., 2016).

\section{Cereal based extruded products}

Cereal based foods remained the predominant diet in the human nutrition for several centuries due to its macronutrient content which is very vital for human metabolism. In some parts of the world it is still regarded as the prime source of energy (Patil, 2016). Cereal as rich source of starch and protein, provides a significant amount of energy to human body nearly $50 \%$ of the world's cereal production is used for human consumption (Brennan, 2012). Most extruded foods are composed of cereals, starches, and/or vegetable protein. The most important attributes for extruded snacks from consumer point of view are crunchiness and crispiness (Corradini and peleg, 2006). The three most widely consumed cereal grains as starch source are wheat, rice and maize. These ingredients provide structure, texture, bulk, crispness and other desirable characteristics to the final product (Launay and Lisch, 1983; Tahnoven et al., 1998; Jamora et al., 2002). Other cereals and starch rich materials, less common used, are rye, barley, oats, sorghum, cassava, tapioca, buckwheat, pea, amaranth and quinoa. For directly expanded products, starch content up to $60 \%$ (dry basis) is required for good expansion. Maize flour provides greater expansion, lowest density to the extrudates while rice extrudates are crispy (Ding, Amsworth and Plunkett). Wheat flour used as ingredient in extrusion industry 
however expansion of extrudates decreases as amylopectin increases (Huang, 2001) therefore maize expands more than rice and wheat. Wheat flour requires high temperature $\left(170^{\circ} \mathrm{C}\right)$ to expand than the maize flour. However the physico-chemical and sensory properties of extrudates depends on process variables and varies among different flours therefore suitable raw material is chosen according to the product requirement and extrusion condition.

Value addition of extruded products with legumes

Legume grains contain approximately $20-30 \%$ protein, although this may vary according to species and cultivar (Iqbal et al., 2006). Legume protein has several health benefits as they are a rich source of essential amino acids such as lysine, and are relatively low in Sulphur containing amino acids such as cysteine, methionine and tryptophan (Rashid et al., 2015; Iqbal et al., 2006). Amongst the many legume plants which may provide sources of protein and fibre to enhance the nutritional profile of extruded cereal products, Lupin has received much attention due to its high protein content, high dietary fibre composition and low fat content (Rashid et al., 2015). Similarly, faba beans, sword beans, and soya bean have also been used as ingredients to fortify cereal based food products (Neme et al., 2015; Huang et al., 2011). Incorporation of legume flours with corn starch-based extruded snacks has been found to have positive impact on proteins and dietary fiber levels (Berrios, 2006). Legumes have been reported to cause good expansion and recommended for the development of highnutritional, low-calorie snacks (Berrios, 2006). $100 \mathrm{~g}$ serving of extruded snacks with sorghum and cowpea flour would contribute $28 \%$ of the recommended dietary allowance (RDA) for protein which represents a $110 \%$ increase in the protein RDA compared to sorghum only (Pelembe et al., 2002). All these studies have pointed to the potential utilization of legumes to alleviate protein energy malnutrition, a subject concisely reviewed (Temba et al., 2016). The effect of incorporation of different levels of different pulse flour (soy bean and green gram) with cereal flours (wheat and maize) on physical and sensory quality of extruded snacks showed that replacement of wheat-maize mix with $15 \%$ pulse flour had maximum sensory score and nutritional quality (Poonam and Hathan, 2015). Anton et al., (2009) developed extruded product of higher nutrient functionality with corn starch and common bean (Phaseolus vulgaris L) flour. Iwe et al., (2001) reported the processing of soybeansweet potato mixtures as a viable means for achieving food production. Obatolu (2002) reported successful production of improved nutrient and sensory qualities of extruded malted or unmalted millet-soybean mixtures. Non-traditional methods of processing cowpea such as thermal extrusion are needed for broadened applications of dry edible beans.

\section{Value addition of extruded products with millets}

Millets with their micro nutrient content are nearly $3-5$ times nutritionally superior to rice and wheat in terms of minerals, vitamins, dietary fibre (water soluble/ insoluble). Millets are good for people suffering from celiac disease (gluten intolerance). Regular consumption of millets is highly beneficial for post-menopausal women suffering from hypertension and hypercholesterolemia (Millet Network of India, ILSI conference_Dr S J Passi_25th April 2014).

Extrusion process increases the iron availability of the extruded weaning foods based on pearl millet, cowpea and peanut or milk powder by 3.5 to 6.5 times higher than the corresponding roasted weaning foods 
(Cisse et al., 1998). Extrusion of Sorghum, pearl millet, and finger millet flours $(60 \%$ of each) blend with toasted mung bean flour $(30 \%)$ and non-fat dry milk (10\%) enhanced the in vitro protein digestibility of weaning foods (nagappa et al., 1996).

The extruded ready to eat snacks of millet blended with grain legumes $(30 \%)$ and also with defatted soy $(15 \%)$ separately contained $14.7 \%$ and $16.0 \%$ protein with 2.0 and 2.1 protein efficiency ratio values, respectively and found suitable as food supplements to children and mothers (Sumathi et al., 2007).

Twin-screw extruder has been used for making snacks from kodo millet-chickpea flour blend (70:30) (Geetha et al., 2012); pearl millet, finger millet and soybean flour blend (Balasubramanian et al., 2012) or ragi, sorghum, soy and rice (42.03,14.95,12.97 and $30 \%$ ) flour blend (Seth and Rajamanickam, 2012) with desired quality. Kodo-chickpea flour blend gives desirable crispy extrudates at higher screw speed of $280 \mathrm{rpm}$, lower feeder speed $20 \mathrm{rpm}$, and medium to high temperature of $123{ }^{\circ} \mathrm{C}$. About $15 \%$ moisture content of the millet-pulse or millet-soy feed at 10 to $15 \%$ blend ratio appears to be acceptable level (Singh et al., 2008). Microwave cold extrudated puffed barnyard millet based ready to eat fasting foods with acceptable sensory quality (Dhumal et al., 2014) and a protein rich composite SorghumCowpea porridge similar to commercial instant maize-soy porridge in terms of functional properties at $130^{\circ} \mathrm{C}$ and $200 \mathrm{~g} / \mathrm{kg}$ water content has been developed through extrusion cooking. Increase in cowpea resulted in increase in protein content, water absorption index and decrease in Expansion ratio (Pelembe et al., 2002). Devi and Narayanasamy (2013) explored the possibility of preparation of composite millets milk powder with the combination of finger millet and pearl millet to prepare RTC extruded product from composite of millet powder and maida (50:50) within the acceptable range in terms of nutrient content, color, texture and cooking quality and sensory characteristics.

Extrudates of composite mixes comprising of brown finger millet flour, maize flour, rice flour, and full fat soy flour in the ratio of 20:50:20:10oked at $140^{\circ} \mathrm{C}$, screw speed of 300 $\mathrm{rpm}$ and die diameter of $3 \mathrm{~mm}$ produced the most acceptable RTE extrudates in terms of expansion ratio hardness and sensory characteristics with acceptable sensory qualities. It is found that the composite mix (Sawant et al., 2013). The optimum mixture of nixtamalized extruded maize flour (NEMF) 21.2\% and Extruded Chickpea Flour (ECF) $78.8 \%$ was used for producing a weaning food which contained $20.07 \mathrm{~g}$ proteins, $5.70 \mathrm{~g}$ lipids, $71.14 \mathrm{~g}$ carbohydrates, and $3.09 \mathrm{~g}$ minerals/100 g. Furthermore, covering the essential amino acids (EAA) requirements for children 2-5 years old recommended by FAO/WHO, except for Trp, which had a EAA score of 91.81. The weaning food, because of its high protein quality and digestibility could be used to promote children growth $(\mathrm{N}-$ Carrillo et al., 2007). Two ready-to use supplementary foods were produced by extrusion cooking (quality protein maizesoybeans common beans and quality protein maize-soybeans-cowpeas) using the following food ingredients: quality protein maize, soybeans, common beans and cowpeas.

Sugar, vitamins and mineral premix were added (Maseta, 2016). Nwabueze (2007) studied hydration properties of extruded fura from millet and legumes. Filli and Nkama (2007) Developed extruded fura from mixtures of pearl millet and grain legumes flours. Oluwole et al., (2013) successfully prepared extrudates from white yam and bambara nut blends. Filli et al., (2012) studied on Influence of extrusion variables on some functional properties of extruded milletsoybean for the manufacture of fura: A Nigerian traditional food. Millet-soybean fura 
extrudates, extruded millet-soybean blends for fura, millet-bambara groundnut-based fura has also been developed through extrusion cooking (Oyango 2005; Filli et al., 2013b; Filli et al., 2013a). Filli et al., (2011) worked on optimization for the production of high energy density fermented or acidified and extruded uji, a traditional staple in east Africa.

\section{Value addition of extruded products with plant leaves}

According to Kakade et al., 2015 To overcome the malnutrition problem of developing countries we can utilize beetroot green waste for products development as it is nutritionally rich in fiber, protein, carbohydrate, vitamins and minerals. The optimized conditions of extruded product were chickpea powder content $16.03 \%$, BRLP $4.26 \%$ and moisture content $15 \%$. Optimized extruded product contains $3.65 \%$ crude fiber and $10.25 \mathrm{mg} / \mathrm{gm}$ of TPC content. It show that addition of BRLP increase the fiber and TPC content of product.

Yacon stem (Smallanthussonchifolius), Carrot leaf (Daucuscarota) Garlic (Allium sativum) and Japanese green tea (Camellia sinensis), Egoma (Perillaflutescens var. flutescens) Japanese green tea had the highest antioxidant capacity and phenolic content and egoma leaves had the second highest (Limsangouant et al., 2010). The optimized extruded snacks from mustard leaves powder (7.19\%), replaced with composite flour (a combination of rice, chickpea and corn in the ratio of 70:15:15) at a barrel temperature of $120^{\circ} \mathrm{C}$ resulted in increase in protein, crude fiber, antioxidant content and total phenolic content (Rathore and Hathan, 2015). Expanded snacks based on Moringa (Moringaoleifera) leaf powder (MLP) and oat flour showed reduced Expansion of extrudates with increased MLP level (Liu et al., 2011). The developed supplemented snacks had higher protein, ash, iron and low carbohydrate in comparison to the control (corn snacks). Iron rich foods like moth bean, lotus stem (LS), karonda (KP), garden cress and niger seeds (GC and NS), amaranth and Bengal gram leaves (AL and BL), 2.5-10\% and acceptability 7.5-10\%.

The mustard leaves powder was replaced with composite flour (a combination of rice, chickpea and corn in the ratio of 70:15:15). The optimum conditions obtained were $7.19 \mathrm{~g}$ mustard leaves powder in 100g premix having 16.8\% moisture content (Rathore and Hathan, 2015).

Mulberry leaf in dried powder(5\% mulberry content) form was mixed with rice, corn, soy, sugar, oil, vitamins and minerals to develop extruded snacks at $300 \mathrm{rpm}$ and $15 \%$ feed moisture (Charunuch et al., 2007).

Amaranth leaf flour was incorporated into yellow maize and soybean (70:30) composite flour at $0,5,10,15$ and $20 \%$ replacement levels to develop extruded snacks and the incorporation of amaranth leaf with soybean flour increased protein, mineral and vitamin contents, bulk density, $\mathrm{pH}$ and oil absorption capacity of the extrudates significantly while addition of amaranth leaf flour reduced expansion ratio, water absorption capacity and significantly of the extrudates (Nkesiga and Okafor, 2015)

\section{Fruits and their by-products utilization for value added extruded products}

Fruits are an important part of the human diet as they provide an abundant amount of vitamins and minerals. There is trend towards healthy snacks. Enrichment with fruits and vegetable increases the level of bioactive compounds in extrudates (Brennan et al., 2011). Fruits and vegetable powder can be incorporated with whole cornmeal to prepare healthy extruded snacks (Karkle et al., 2009). 


\section{Studies on nutritional changes after extrusion cooking}

\begin{tabular}{|c|c|c|c|}
\hline Authors & Ingredients & Extrusion condition & $\begin{array}{l}\text { Change in } \\
\text { nutrients }\end{array}$ \\
\hline $\begin{array}{l}\text { Borejszo and } \\
\text { Khan,1992 }\end{array}$ & Pinto beans & $\begin{array}{l}\text { Die temperature-110- } \\
163 \\
\text { Screw speed-300rpm } \\
\text { Feed moisture- } \\
18.8 \%\end{array}$ & $\begin{array}{l}\text { ( }) \text { raffinose and } \\
\text { stachyose }\end{array}$ \\
\hline $\begin{array}{ll}\text { Omueti } & \text { and } \\
\text { Morton,1996 }\end{array}$ & Corn and soy & & $\begin{array}{l}\text { ( } \downarrow) \text { raffinose and } \\
\text { stachyose }\end{array}$ \\
\hline Iwe et al.,2004 & $\begin{array}{l}\text { Defatted soy flour and } \\
\text { sweet potato flour }\end{array}$ & $\begin{array}{l}\text { Screw speed } 80-140 \\
\text { rpm } \\
\text { Die diameter }(10- \\
6 \mathrm{~mm})\end{array}$ & $\begin{array}{l}(\uparrow) \text { Lysine } \\
\text { retention }\end{array}$ \\
\hline Iwe et al.,2001 & Maize grits & $\begin{array}{l}\text { Feed moisture 12- } \\
25 \% \\
\text { Mass temperature- } \\
181-187\end{array}$ & $(\downarrow)$ cysteine \\
\hline Varo et al.,1983 & $\begin{array}{l}\text { Wheat flour and } \\
\text { whole wheat meal }\end{array}$ & $\begin{array}{l}\text { Mass } \\
\text { temperature(161-180) } \\
\text { Feed moisture- } 15 \% \\
\text { Screw speed -150- } \\
\text { 200rpm }\end{array}$ & Dietary fibre \\
\hline $\begin{array}{l}\text { Vasanthan } \\
\text { al.,2002 }\end{array}$ & Barley flour & $\begin{array}{l}\text { Temperature } 90-140 \\
{ }^{\circ} \mathrm{C} \text { and } 20-50 \% \\
\text { moisture level. }\end{array}$ & $\begin{array}{l}(\uparrow) \text { soluble and } \\
\text { insoluble dietary } \\
\text { fibre }\end{array}$ \\
\hline
\end{tabular}

*( $\uparrow)$ increased, $(\downarrow)$ decreased

Some authors have reported acceptable extruded product with Guava pulp and wheat grits; dried flour of cactus pear (Gandhi and Singh, 2015; Sarkar et al., 2011). 50\% of whole cornmeal can be replaced by the nutrient dense powder of lotus stem, kulfa leaves and gooseberry Carrot pomace (up to $8.25 \%$ ) can be incorporated as a source of dietary fibre and vitamins (Kumar et al., 2010). Soluble phenolics and anthocyanins were higher in the fruit cereals. Altan et al., 2008 used Blends of barley flour and tomato pomace and reported that extrudates with $2 \%$ and $10 \%$ tomato pomace levels extruded at $160{ }^{\circ} \mathrm{C}$ and $200 \mathrm{rpm}$ had higher preference levels for parameters of color, texture, taste and overall acceptability.

For extrusion, fruit powder of apple, banana, strawberry and tangerine were added at a level of $11 \%$ and found that fruit powder has significant $(\mathrm{P}<0.05)$ effect on expansion and density of the extrudates. Extruded products had improved nutritional profile, being low in fat and sugar and a good source of fibre as both soluble and insoluble fibre increased substantially (Potter et al., 2013). Karkle et al., 2012 developed corn based extruded product with apple pomace. Corn based snacks with added cranberry pomace and 
grape pomace was also developed (white et al., 2010; Khanal et al., 2009a)

\section{Vegetable and their by-products utilization for value added extruded products}

Dried and milled cauliflower at levels of 5$20 \%$ was added with wheat flour, oat flour, corn starch, egg white, milk powder, onion powder, tomato powder, carrot powder, dill and mint, paprika and salt and the taste panel acceptability score showed that cauliflowerby-products could be added up to 10\% (Stojceska et al., 2008a). Cauliflower by-products were found to increase the antioxidant, fibre and protein content of extruded snacks (Stojceska et al., 2008a). Extrusion cooking enhanced the antioxidant capacity and total phenolic compounds in the samples containing red cabbage (Stojceska et al., 2009). Oke et al., (2013) worked on assessment of microbial changes and nutritional qualities of extruded white yam (Dioscorea rotundata) and bambara groundnut (Vigna subterranean) blends. Diet intake was quadratically affected by feed moisture and screw speed in rat fed extruded African breadfruit-based diets. Bioavailability of vitamins and minerals in adult rats fed raw and extruded African breadfruit (Treculia african) mixtures (Nwabueze et al., 2008).

\section{Extruded products of animal origin}

Mosha and Bennink (2005) fed four supplementary foods, namely, corn-beansardine meal (CBSM), bean meal (BM), sorghum-bean-sardine meal (SBSM), and rice-bean-sardine meal (RBSM) processed by extrusion, drum processing and conventional cooking to the animal. They reported that animals fed extruded products gained more weight relative to those fed drum-processed and conventionally cooked foods. The true protein digestabilities were significantly $(\mathrm{P}<$ 0.05) higher when extruded foods, compared with drum-processed and conventionally cooked foods, were fed to experimental animals. With the increase in fish and wheat flour ratio the digestibility of extruded snacks increases (Bhattacharya et al., 1988; Camire et al., 1990). Corn-fish extruded snacks, containing freeze-dried saithe protein, were developed with no odour and flavour changes during storage (Shaviklo et al., 2011).

Extrusion cooking of fish and rice-flour blends in a single-screw cooking extruder was done to develop acceptable snacks (Jaya Shankar and Bandyopadhyay, 2005). Extruded chicken products have also been texturized by extrusion (Kitabatake et al., 1985). Ground beef has also been blended with yellow and white corn flour (smithey et al., 1995).

\section{Milk based extruded snacks}

Including whey protein and whey permeate in ready-to-use supplementary food improves recovery rates in children with moderate acute malnutrition. Whey is the serum or liquid part of milk that is a by-product of cheese and curd manufacturing (stobaugh et al., 2016). Incorporation of 5\% Whey Protein Concentrate (WPC) in pearl millet grits (841 $\mu)$ was recommended to develop nutritious acceptable extruded snacks (Yadav et al., 2014). Nutritious high-protein puffed snacks of corn meal with texturized whey protein isolate was developed with acceptable physico-chemical properties. Whey protein isolate were modified/texturized using a twinscrew extruder to minimize the water binding property of dairy proteins which can be used to boost the protein content in puffed snacks (Onwulata et al., 2010). Sweet whey solids (SWS) or whey protein concentrate (WPC) were added at concentrations of 250 and 500 $\mathrm{g} / \mathrm{kg}$ to corn meal, rice, or potato flour to make snack products (Onwulata et al., 2001). Wet extrusion was used to prepare cheese 
analogues from caseinate and butter oil, and fat analogues from whey protein isolates (Cheftel et al., 1992). Devi et al., (2010) developed highly acceptable extruded product from sorghum/corn flour (5:2) with whey protein isolate-defatted soy flour as the protein source.

\section{The potential effect of extrusion on nutrient composition}

The food components that play an important role in the extrusion cooking processes are: starch, proteins, lipids, low molecular sugars, and fibres. Starch conversion leads to the loss of crystalline structure to form an amorphous phase, which in extrusion cooking of the starch rich materials results in a fluid mass with starch biopolymers in the continuous phase. This helps to retain the gases released during the expansion process at the extruder die, enabling the formation of expanded foam structures. The amount of polymer, which is found in the continuous phase determines the extensibility of bubble cell walls in the foam and therefore the overall expansion of extrudates at the die (Guy, 2001). Extrusion cooking disrupts the structure and crystallinity of starch granules resulting in gelatinisation and improves quality and characteristics of starch (Hui, 2006).

Recent research has illustrated that extrusion cooking plays an important role in restricting presence of anti-nutritional compounds, the mechanical and chemical process leads to increase in protein digestion by denaturation protein structures (Patil 2016). The retention and loss of nutrients depends on the process variables i.e. barrel temperature, screw speed, moisture and die diameter.

Additionally, extrusion process can be useful in lysine retention of cereal-based snacks, increasing screw speed and decreasing the die diameter helps in upgrading lysine maintenance (Singh et al., 2007). During extrusion process the elastic swell and bubble growth effect contributes to structural changes of starch (Padmanabhan and bhattacharya, 1989). Through extrusion processing protein and starch digestibility, as well as the antioxidant activity of the final product based on chickpea and wheat blends, could be significantly improved (Yagci and Evci, 2015). During extrusion degradation of pea proteins, results in formation of peptide bonds through covalent bonding. This mechanism of improving protein digestibility has been linked to protein reorganisation during extrusion (Osen et al., 2015). Lycopene retention was higher in product incorporated with tomato skin powder while addition of wheat flours lowered the lycopene content of extrudates (Shoar et al., 2010). Mild extrusion enhances the nutritional value of vegetable protein and improves digestibility (Srihara and Alexander, 1984; Areas, 1992). This is due to the protein denaturation and inactivation of enzyme inhibitors present in raw plant foods and anti-nutritional factors, especially trypsin inhibitors, haemagglutinins, tannins and phytates that interferes in protein diestibility (Colonna et al., 1989; Bookwalter et al., 1971; Lorenz and Jansen, 1980). Stojceska et al., (2009) reported that increase in water feed to $15 \%$ increased the total dietary fibre, antioxidant and phenolic content levels. Extrusion cooking affects the vitamin stability in the extrudates. Minimising temperature and shear within the extruder protects most vitamins. Thermal degradation appears to be the major factor for betacarotene losses during extrusion thiamine has been reported most frequently followed by riboflavin, ascorbic acid and vitamin A (Guzman-Tello and Cheftel,1990). Extrudates from Short barrel $(90 \mathrm{~cm})$ extruder had higher retention rate of $\mathrm{B}$ vitamin group (44-62\%) than the long barrel extruders (Athar et al., 2006). High temperature and short time extrusion cooking influence the fat soluble 
vitamin stability such as vitamin $\mathrm{A}$ and $\mathrm{E}$ (Tiwari and Cummins, 2009).

Formation of amylose-lipid complex is evident during extrusion. The extent of amylose-lipid complex formation depends on type of starch and lipid present in food. Flatulence causing oligosaccharides are found to be decreased after extrusion cooking (Borejszo and Khan, 1992; Omueti and Morton, 1996) which improves the nutritional quality. Under milder extrusion condition for wheat no significant change in fibre was observed, but the fibre present became slightly more soluble (Siljestrom et al., 1986). At mild or moderate conditions, extrusion cooking does not significantly change dietary fibre content but it solubilises some fibre components. At more severe condition the dietary fibre content tends to increase, mainly owing to the increase in soluble dietary fibre and enzyme resistant starch fractions (Singh et al., 2007).

It is concluded that various value added supplementary and weaning food has been developed using extrusion technology. Triposha in Srilanka is a popular extruded product of soybean . Nutritional extruded product of soy and wheat (25:75) with added sugar vitamin pre-mix is being distributed to malnourished population with the help of funding from WFP (Ali and Patil, 1986). The versatility of extrusion technology makes it convenient for development of nutritionally rich extruded products with wide range of raw material and useful as a source of vehicle for value addition. Extruded products have less moisture, longer shelf life, microbiologically safe and there are plenty of ways to make value added and fortified extruded products with combination of different raw materials. The extrusion technology is a well-known and widely accepted tool and can be used to overcome malnutrition problems so as to improve health and food security worldwide.
However, challenges to extrusion processing in developing economies include: (1) lack quality grain supply; (2) unavailability of extension of existing processing technology; (3) nutritional myths like poor digestibility; (4) governmental policy; (5) poor image of sorghum and millets; (6) logistics and markets issues; (7) few shelf-stable convenience foods; and (8) grain storage facilities and (9) grain microbial contamination such as grain mold. Extruded product needs vary from country to country. The attention should be given to the questions like, the effect policy makers on distribution of processing plants, raw materials availability, and requirements of a population. Extrusion technology should be included as a part of food production at national level.

\section{References}

Altan A, Kathryn L. M, Medeni M, 2008. Evaluation of snack foods from barleytomato pomace blends by extrusion processing. Journal of Food Engineering. 84(2), 231-242.

Balasubramanian S., et al., 2011. Effect of selected dehulled legume incorporation on functional and nutritional properties of protein enriched sorghum and wheat extrudates. Journal of Food Science Technology, 49(5): 572-579.

Baskaran V, Bhattacharaya S. 2004. Nutritional status of the protein of cornsoy based extruded products evaluated by rat bioassay. Plant Foods Hum Nutr. Summer, 59(3):101-4.

Bhattacharya S, Das H and Bose AN 1988. Effect of extrusion process variables on in vitro protein digestibility of fishwheat flour blends. Food Chemistry, 28: 225-231.

Boonyasirikool, P. and Charunuch, C. 2000. Development of nutritious snack by extrusion cooking. Kasetsart J. Nat. Sci. 34: 355-365. 
Boye J I., et al., 2012. Comparison of the functional properties of pea, chickpea and lentil protein concentrates processed using ultrafiltration and isoelectric precipitation techniques. Food Research International, 43(2): 537-546.

Brennan C, Brennan M, Derbyshire E, Tiwari BK. 2011. Effects of extrusion on the polyphenols, vitamins and antioxidant activity of foods. Trends Food Sci Technol. 22: 570-575.

Brennan MA., 2012. Amaranth, millet and buckwheat flours affect the physical properties of extruded breakfast cereals and modulates their potential glycaemic impact”. Starch - Stärke 64(5): 392-398.

Bressani R, Harper JM, Whickstrom B 1984. Processed and package weaning foods: Development, manufacture and marketing. In: Mitzner N, Scrimshaw N,Morgan R (eds), Improving the Nutritional Status of Children During Weaning Period. International Food and Nutrition Program, MIT, Cambridge, MASS, USA.

Camire ME, Camire AL and Krumhar $\mathrm{K}$ 1990. Chemical and nutritional changes. Critical Reviews in Food Science and Nutrition, 29: 35-57.

Charles S. Brennan., et al., 2016. The Potential of Combining Cereals and Legumes in the Manufacture of Extruded Products for a Healthy Lifestyle. EC Nutrition, 5(2): 11201127.

Charunuch, C., Tangkanakul, P., Rungchang, S., Sonted, V. 2007. Application of Mulberry (Morus alba) for Supplementing Antioxidant Activity in Extruded Thai Rice Snack. In Proceeding of International Workshop on Medicinal and Aromatic Plants, Chiang Mai, Thailand, 15-18 January 2007; pp. 137-146. Int. J. Mol. Sci. 13. 6662 .
Cheftel, J. C., Kitagawa, M. and Queguiner, C. 1992. New protein texturization processes by extrusion cooking at high moisture levels. Food Rev. Int. 8: 235275

Devi, N.L., Shobha, S., Tang, X., Shaur, S.A., Dogan, H. and Alavi, S. 2013. Development of Protein-Rich SorghumBased Expanded Snacks Using Extrusion Technology. International Journal of Food Properties, 16: 263-276

E.L. Karkle, L. Keller, H. Dogan, S. Alavi. 2012. Matrix transformation in fiberadded extruded products: Impact of different hydration regimens on texture, microstructure and digestibility. Journal of Food Engineering, 108: 171-182

Filli, K.B., and Nkama, I. 2007. Hydration properties of extruded fura from millet and legumes. British Food J. 109(1): 6880.

Filli, K.B., Nkama, I., Jideani, V.A., and Abubakar, U.M. 2013b. Application of response surface methodology for the evaluation of proximate composition and functionality of millet-soybean fura extrudates. Wudpecker J. Food Technol. 1(5): 074-092.

Filli, K.B., Nkama, I., Jideani, V.A., and Ibok, I.U. 2013a. Effect of process variables on the hydration properties and acceptability of extruded millet soybean blends for fura manufacture. British Food J. 115(6): 884-898.

Filli, K.B., A.I.O. Jideani, V.A. Jideani. 2014. Extrusion bolsters food security in Africa Food Technol., 68(8): 45-55.

Gandhi N and Singh B, 2015. Study of extrusion behaviour and porridge making characteristics of wheat and guava blends. J Food Sci Technol. 52(5): 3030-3036.

Gulati P., "Effects of feed moisture and extruder screw speed and temperature on physical characteristics and antioxidant activity of extruded proso 
millet flour". International Journal of Food Science and Technology., 50(2016): 114-122.

Guy, R. 2001. Extrusion cooking: technologies and applications, Woodhead Publishing, Cambridge, United Kingdom.

Guzman-Tello, R. and Cheftel, J.C. 1987. Thiamine destruction during extrusion cooking as an indicator of the intensity of thermal processing. International Journal of Food Science and Technology., 22, 549-562

Harper JM, Jansen GR 1985. Production of Nutritious Foods in Developing Countries by Low-Cost Extrusion Technology. Food Reviews International, 1: 27-97.

Huang SY., et al., 2011. Modification of insoluble dietary fibres in soya bean okara and their physicochemical properties. International Journal of Food Science and Technology., 50: 2606-2613.

Imtiaz, H., BurhanUddin, M. and Gulzar, M.A. 2011. Evaluation of weaning foods formulated from germinated wheat and mungbean from Bangladesh. African Journal of Food Science, 5: 897-903.

Indian Standard. Processed-cereal based complementary foods - specification (Second Revision) December 2006.

Iqbal A., et al., 2006. Nutritional quality of important food legumes. Food Chemistry, 97(2): 331-335

Jaya Shankar T and Bandyopadhyay S. 2005. Process variables during single-screw extrusion of fish and rice-flour blends. Journal of Food Processing and Preservation. 29(2): 151-164.

Kakade S.B., Hathan B.S, Neeha VS, 2015. Utilization of beetroot (Beta vulgaris L.) Leaves powder in cereals based extruded product. International
Research Journal of Engineering and Technology. 2(3): 2153-2161.

Karkle E L Alavi S Dogan H Jain S and Waghray K 2009. Development and evaluation of fruit and vegetable based extruded snacks. Online AACC International Cereal Science Knowledge.

Karkle, E. L., Keller L., Dogan H. and Alavi, S. 2012. Matrix transformation in fiberadded extruded products: Impact of different hydration regimens on texture, microstructure and digestibility. J. Food Eng. 108: 171-182.

Khanal, R. C., Howard, L. R., Brownmiller, C. R. and Prior, R. L. 2009a. Influence of extrusion processing on procyanidin composition and total anthocyanin contents of blueberry pomace. J. Food Sci. 74(2): 52-58.

Khanal, R. C., Howard, L. R. and Prior, R. L. 2009b. Procyanidin content of grape seed and pomace, and total anthocyanin content of grape pomace as affected by extrusion processing. J. Food Sci. 74: 174-182.

Kitabatake, N., Megard, D. and Cheftel, J. C. 1985. Continuous gel formation by HTST extrusion-cooking: Soy proteins. J. Food Sci. 50: 1260-1265.

Kumar V. et al., 2010. Dietary roles of phytate and phytase in human nutrition: A review. Food Chemistry 120.1 (2010): 945-959

Leszek M, van Zuilichem DJ 2011. Extrusion-Cooking and Related Techniques In: Extrusion-Cooking Techniques: Applications, Theory and Sustainability. Pp. 1-24.

Limsangouan N,, Takenaka M, Sotom E I, Nanayama $\mathrm{K}$, Charunuch $\mathrm{C}$ and Isobe $\mathrm{S}$, 2010. Functional Properties of Cereal and Legume Based Extruded Snack Foods Fortified with By-Products from Herbs and Vegetables, Kasetsart J. (Nat. Sci.) 44: $271-279$. 
Liu S, Alavi S and Abughoush M, 2011. Extruded Moringa Leaf-Oat Flour Snacks: Physical, Nutritional, and Sensory Properties. International Journal of Food Properties.14(4):854869.

Maseta E, Mosha T C, Nyaruhucha C, Laswai H 2017. Nutritional quality of quality protein maize-based supplementary foods. Nutrition and Food Science 47(1): 42-52.

Maya S. Rathod, Bahadur Singh Hathan, 2015. Utilization of Mustard Leaves (Brassica juncea) Powder for the Development of Cereal Based Extruded Snacks, World Academy of Science, Engineering and Technology International Journal of Biological, Biomolecular, Agricultural, Food and Biotechnological Engineering 9(8).

Michaelsen K. F., Lauritzen L., Mortensen E. L. 2009. Effects of breast-feeding on cognitive function, in Breast-feeding: early influences on later health, eds Goldberg G., Prentice A., Prentice A., Filteau S., Simondon K., editors. (Netherlands: Springer).

Moscicki, L., Van Zuilichem, D.J. Extrusioncooking and related technique. in: $\mathrm{L}$. Moscicki (Ed.) Extrusion-Cooking Techniques, Application, Theory and Sustainability. Wiley-VCH Verlag GmbH \& Co. KGaA, Weinheim; 2011: $1-24$.

Mosha, T. C. and Bennink, M. R., 2005. Protein digestibility-corrected amino acid scores, acceptability and storage stability of ready-to-eat supplementary foods for pre-school age children in Tanzania. J. Sci. Food Agric., 85: 15131522.

Nagappa G. Malleshi Nirmala A. Hadimani Rangaswami Chinnaswamy Carol F. 1996. Klopfenstein Physical and nutritional qualities of extruded weaning foods containing sorghum, pearl millet, or finger millet blended with mung beans and nonfat dried milk Plant Foods for Human Nutrition, 49(3): 181-189.

Neme K., et al., 2015. Nutrient and functional properties of composite flours processed from pregelatinised barley, sprouted faba bean and carrot flours. International Journal of Food Science and Technology., 50(11): 2375-2382.

Nipat Limsangouan, Makiko Takenaka, Itaru Sotome, Kazuko Nanayama, Chulaluck Charunuch and SeiichiroIsobe Functional Properties of Cereal and Legume Based Extruded Snack Foods Fortified with By-Products from Herbs and Vegetables, Kasetsart J. (Nat. Sci.) 44: 271 - 279 (2010).

Nkesiga J. and Okafor G. I. 2015. Effect of incorporation of amaranth leaf flour on the chemical, functional and sensory properties of yellow maize/soybean based extrudates. IOSR Journal of Environmental Science, Toxicology and Food Technology (IOSR-JESTFT), 9(7): 31-40.

Nwabueze, T. U., Iwe, M. O. and Akobundu, E. N.T. 2008. Physical characteristics and acceptability of extruded African breadfruit-based snacks. Journal of Food Quality, 31(2):142-155.

Nwabueze, T.U. 2007. Bioavailability of vitamins and minerals in adult rats fed raw and extruded African breadfruit (Treculia african) mixtures. J. Food Agriculture Environ. 5(314): 465-470.

Oke MO, Awonorin SO and Workneh TS 2013. Expansion ratio of extruded water yam (Dioscorea alata) starches using a single screw extruder. African Journal of Agricultural Research, 8(9): 750-762.

Oluwole, O.B., Awonorin, S.O., Henshaw, F., Elemo, G.N., and Ebuehi, O.A.T. 2013. Assessment of microbial changes and nutritional qualities of extruded white yam (Dioscorea rotundata) and 
bambara groundnut (Vigna subterranean) blends. Food Nutri. Sci. 4: 100-107.

Onwulata, C. I., 2010. Use of extrusiontexturized whey protein isolates in puffed corn meal. J. Food Process. Preserv. 34(2): 571-586.

Onwulata, C. I., Konstance, R. P., Smith, P. W. and Holsinger, V. H. 2001. Coextrusion of dietary fiber and milk proteins in expanded corn products. LebensmittelUntersuch. Forsch. $34: 424-429$

Oyango, C., 2005. Process optimization for the production of high energy density fermented or acidified and extruded uji. Dissertation submitted for the Award of Doctor Ingenieur (Dr.-Ing.). Fakultat Maschinenwesen Institut for Lebensmithtel und Bioverfahrenstechhnik Technische Universitat Dresden, Dresden, Germany.

Oyango, C., 2005. Process optimization for the production of high energy density fermented or acidified and extruded uji. Dissertation submitted for the Award of Doctor Ingenieur (Dr.-Ing.). Fakultat Maschinenwesen Institut for Lebensmithtel und Bioverfahrenstechhnik Technische Universitat Dresden, Dresden, Germany.

Pelembe, L.A.M., Erasmus, C., and Taylor, J.R.N. 2002. Development of a proteinrich composite sorghum-cowpea instant porridge by extrusion cooking process. Lebensm - Wiss. U. - Technol. 35: 120 $-127$.

Potter R, Stojceska, V, Plunkett A. 2013. The use of fruit powders in extruded snacks suitable for Children's diets; Food Science and Technology - lwt. Lebensmittel-Wissenschaft und Technologies. 51(2): 537-544
Rashid S., et al., 2015. Effects of extrusion cooking on the dietary fibre content and water solubility index of wheat bran extrudates. International Journal of Food Science and Technology., 50(7): 1533-1537.

Rathod M S and Hathan B S. 2015. Utilization of Mustard Leaves (Brassica juncea) Powder for the Development of Cereal Based Extruded Snacks, International Journal of Biological, Biomolecular, Agricultural, Food and Biotechnological Engineering, 9(8): 880-884.

Riaz, M. 2013. Introduction to Extrusion. Presented at the ExtruAfrica Conference, "Needs, barriers and opportunities for extrusion in Africa", at Protea hotel Kruger Park, Skukuza Mpumalanga province, South Africa, August 1-2.

Sarkar P, Setia N and Choudhury G S. 2011. Extrusion processing of cactus pear. Advance Journal of Food Science and Technology., 3(2):102-110.

Sawant AA, Thakor NJ, Swami SB and Divate AD. 2013. Physical and sensory characteristics of Ready-to-Eat food prepared from finger millet based composite mixer by extrusion cooking. Agricultural Engineering International: CIGR Journal, 15(1): 100-105.

Shaowei Liu, SajidAlavi, and Mahmoud Abughoush International Journal of Food Properties Vol. 14, Iss. 4, 2011. Extruded Moringa Leaf-Oat Flour Snacks: Physical, Nutritional, and Sensory Properties

Shaviklo, G. R., Thorkelsson, G., Rafipour, F. and Sigurgisladottir, S. 2011. Quality and storage stability of extruded puffed corn-fish Snacks during 6- month storage at ambient temperature. J. Sci. Food Agric. 91(5): 886-893.

Shoar, Z. D., Hardacre, A. K. and Brennan, C. S. 2010. The physico-chemical 
characteristics of extruded snacks enriched with tomato lycopene. Food Chem. 123:1117-1122.

Singh JP., et al., 2016. Physiocochemical characterisation of corn extrudates prepared with varying levels of beetroot at different extrusion temperatures". International Journal of Food Science and Technology., 51(4): 911-919.

Singh, S., Gamlath, S. and Wakeling, L. 2007b. Nutritional aspects of food extrusion: A review. Int. J. Food Sci. Technol. 42(8): 916-929.

Smithey, S. L., Badding, Huff H. E. and Hsieh E. 1995. Processing parameters and product properties of extruded beef with nonmeat cereal binders. LWT Food Sci. Technol. 28: 386-394.

Stobaugh, H. C., Ryan, K. N., Kennedy, J. A., Grise, J. B., Crocker, A. H., Thakwalakwa, C., Litkowski, P. E., Maleta, K. M., Manary, M. J., andTrehan, I. 2016. Including whey protein and whey permeate in ready-touse supplementary food improves recovery rates in children with moderate acute malnutrition: a randomized, double-blind clinical trial. American Journal of Clinical Nutrition, 103: 926933.
Stojceska, V., Ainsworth, P., Plunkett, A., Ibanoglu, E. and Ibanoglu, S. 2008a. Cauliflower by-products as a new source of dietary fibre, antioxidants and proteins in cereal based ready-to-eat expanded snacks. J. Food Eng. 87: 554563.

Stojceska, V., Paul A., Andrew, P. and Senol, I. 2008b. The recycling of brewer's processing by-product into ready-to-eat snacks using extrusion technology. J. Cereal Sci. 47: 469-479.

Sumathi, A., S. R. Ushakumari, and N. G. 2007. Malleshi Physico-chemical characteristics, nutritional quality and shelf-life of pearl millet based extrusion cooked supplementary foods. International Journal Of Food Sciences And Nutrition, 58: 5.

Temba MC., 2016. The role of compositing cereals with legumes to alleviate protein energy malnutrition in Africa. International Journal of Food Science and Technology., 51(3): 543-554.

Yadav D N, Anand T, Navnidhi and Singh A K. 2014. Co-extrusion of pearl milletwhey protein concentrate for expanded snacks. International Journal of Food Science and Technology., 49: 840-846.

\section{How to cite this article:}

Neha Pathak and Anita Kochhar. 2018. Extrusion Technology: Solution to Develop Quality Snacks for Malnourished Generation. Int.J.Curr.Microbiol.App.Sci. 7(01): 1293-1307. doi: https://doi.org/10.20546/ijcmas.2018.701.158 